\title{
A scientific note on the lack of nepotism in queen larval feeding during emergency queen rearing in a naturally mated honey bee colony ${ }^{1}$
}

\author{
Nicolas CHÂLINEa*, Gérard ARNOLD ${ }^{\mathrm{b}}$ \\ ${ }^{\text {a }}$ Laboratory of Apiculture and Social Insects, Department of Animal and Plant Sciences, University of Sheffield, \\ Western Bank, Sheffield, S10 2TN, UK \\ b CNRS UPR 9034, Laboratoire Populations, Génétique et Évolution, 91198 Gif-sur-Yvette, France
}

Received 23 August 2004 - Revised 27 September 2004 - Accepted 28 September 2004

Published online 16 March 2005

Apis mellifera / emergency queen rearing / nepotism/ nurses / DNA microsatellites

Honey bee (Apis mellifera L.) colonies consist of many patrilines (Estoup et al., 1994) and workers can potentially increase their inclusive fitness during queen replacement if they can favour a full-sister offspring queen (Visscher, 1998). There is evidence of preferential rearing of some patrilines in emergency queen rearing (Tilley and Oldroyd, 1997; Osborne and Oldroyd, 1999; Châline et al., 2003), although the reason for this is unclear. Some patrilines could act nepotistically or a "royalty allele" could make some larvae more attractive to workers (Osborne and Oldroyd, 1999). Early studies on behavioural interactions and larval preferences during queen rearing used colonies with limited numbers of patrilines or cross-fostering of larvae between unrelated colonies with naturally mated queens. They showed weak or no evidence of nepotism (Breed et al., 1984; Noonan, 1986; Page et al., 1989). To avoid the problem of unnaturally low number of patrilines and the use of artificial insemination, we used microsatellites to analyse the kinship of feeding workers and queen larvae during emergency queen rearing, for the first time in a colony with a naturally mated queen.

The experiment was carried out in double blind in a queenless observation hive containing individually marked bees. This was done by marking bees emerging from two brood combs of the test colony over 6 consecutive days. Before the experimental colony set-up, the marked bees were returned to their mother colony to ensure a normal ontogeny. Twentyfour hours before the set-up, 50 queen cells were initiated in a queen rearing colony by grafting larvae from the test colony. Thirteen of these were then attached to a brood comb from the test colony and transferred in an observation hive with 2000 of the marked workers. During the experiment, three additional queen cells were built naturally.

Each queen cell was observed individually for $1 / 2 \mathrm{~h}$ every day until capping. The total observation time was $2130 \mathrm{~min}$. The bees feeding each queen larvae were recorded, as this seemed the best behaviour for the

\footnotetext{
* Corresponding author: nicolas.chaline@univ-tours.fr

Present address: IRBI, CNRS UMR 6035, Faculté des Sciences, Parc Grandmont, 37200 Tours, France.

${ }^{1}$ Manuscript editor: Stan Schneider
} 
expression of nepotism. The queen pupae (16) and marked adult workers (1300 left due to drifting and predation) were then collected together with a control sample of worker larvae. The patriline of each sample was determined with three microsatellite markers (A76, A29 and B124, Estoup et al., 1994).

There were 21 patrilines in the colony (effective paternity $=11.65$ ). The queens belonged to 9 patrilines. During the observations, 172 workers performed 183 feedings. Of these 172 workers, 97 could be retrieved (107 feedings). The repartition of feeding nurses $(n=97)$ in the different patrilines was not significantly different from the control sample (n $=136 ; P=0.21$, Fisher's exact test using the program "Monte Carlo RxC 2.2" by W. Engels, University of Wisconsin). The overall proportion of workers feeding queens of their own patriline was 0.065 which is not different from the random chance of encountering a full sister with an effective paternity of 11.65 $\left(0.086 ; \chi^{2} P>0.1, \mathrm{df}=1, \mathrm{n}=107\right)$. A correspondence analysis showed no association between the queens and nurses patrilines.

Our results did not show any tendency of workers to bias their behaviour towards closer kin. This suggests that no nepotism occurred in this colony during emergency queen rearing, and confirms the results of other studies (Breed et al., 1984, 1994). Because the sample size was small relative to the number of patrilines, it is possible that weakly expressed nepotism could not be seen. Page et al. (1989), with colonies containing three patrilines, found that a likely mechanism for the observed bias was that some patrilines are overrepresented in the nurses and alter the outcome of queen rearing, but no such specialist patrilines were found here. The use of grafted larvae could also be the reason for a lack of nepotism as the initial larval selection process may be where the differences occur (Visscher, 1998). After this step, the risk of failing to rear a queen may be too costly for any bias to be expressed (Tarpy et al., 2004). Our study is the first behavioural study of queen rearing using a naturally mated queen. Although the sample size was necessarily small, it confirms the findings of earlier studies that nepotism is probably absent or weakly expressed during this process (Tarpy et al., 2004).

Note scientifique sur l'absence de népotisme dans l'alimentation des larves royales pendant l'élevage de reines de remplacement dans une colonie d'abeilles dont la reine s'est accouplée naturellement.

Eine wissenschaftliche Notiz über das Fehlen von Nepotismus während der Fütterung von Nachschaffungsköniginnen in einem Volk mit natürlich gepaarter Königin.

\section{REFERENCES}

Breed M.D., Velthuis H.H.W., Robinson G.E. (1984) Do worker honey bees discriminate among larval genotypes? Ann. Entomol. Soc. Am. 77, 737-739.

Breed M.D., Welch C.K., Cruz R. (1994) Kin discrimination within honey bee (Apis mellifera) colonies - An analysis of the evidence, Behav. Proc. 33, 25-39.

Châline N., Arnold G., Papin C., Ratnieks F.L.W. (2003) Patriline differences in emergency queen rearing in the honey bee, Apis mellifera, Insectes Soc. 50, 234-236.

Estoup A., Solignac M., Cornuet J.M. (1994) Precise assessment of the number of patrilines and of genetic relatedness in honeybee colonies, Proc. R. Soc. London B 258, 1-7.

Noonan K.C. (1986) Recognition of queen larvae by worker honey bees Apis mellifera, Ethology 73 , 295-306.

Osborne K.E., Oldroyd B.P. (1999) Possible causes of reproductive dominance during emergency queen rearing by honeybees, Anim. Behav. 58, 267-272.

Page R.E., Robinson G.E., Fondrk M.K. (1989) Genetic specialists, kin recognition and nepotism in honeybee colonies, Nature 338, 576-579.

Tarpy D.R., Gilley D.C., Seeley T.D. (2004) Levels of selection in a social insect: a review of conflict and cooperation during honey bee (Apis mellifera) queen replacement, Behav. Ecol. Sociobiol. 55, 513-523.

Tilley C.A., Oldroyd B.P. (1997) Unequal subfamily proportions among honey bee queen and worker brood, Anim. Behav. 54, 1483-1490.

Visscher P.K. (1998) Colony integration and reproductive conflict in honey bees, Apidologie 29, 23 45 . 